\title{
Ratification of the CISG: A Way Forward to Ensure Success of the African Continental Free Trade Area (AfCFTA)
}

\author{
Rita Mawufemor Tsorme \\ PhD Candidate in International Law, School of Law, Xiamen University, China
}

\begin{abstract}
The African Continental Free Trade Area (AfCFTA) established in March 2018 has recently commenced trading under the free trade area on the $1^{\text {st }}$ January 2021. Except for Eritrea, all the remaining 54 member states of the Africa union signed up to the agreement. Ever since the WTO creation, the Africa Continental Free Trade Area is considered the largest in the world in terms of the number of contracting states. Several authors have indicated that the establishment of this agreement is a success to Africa. However, the researcher believes that the uniformity of laws concerning the international sale of goods has become crucial for the smooth operations of African Trade. The UN Convention on Contracts for the International Sale of Goods (CISG) is a breakthrough effort by the United Nations Commission on International Trade Law (UNCITRAL) to unify the laws pertaining to contracts for the international sale of goods. This study argues that, for a smooth operation of the AfCFTA, there is a need for all African countries to sign and ratify the CISG which is also known as the Vienna Convention. The proposed appeal holds benefits for the continent and it is easy and judicious to implement.
\end{abstract}

Keywords: AfCFTA, CISG, Africa

DOI: $10.7176 /$ JLPG/107-01

Publication date:March $31^{\text {st }} 2021$

\section{Introduction}

Over the years, most states across the globe have been putting in efforts to enhance their economy by developing their commercial and legal systems. It has been done either by amending outdated rules of law or adopting modern laws. The motive for adopting various laws was to encourage international investors and traders from other states to invest in these countries. The African continent is progressively seeing the need for modernization and harmonization of laws regarding its commercial activities. However, the implementation of international uniform laws in several parts of the continent has still been sluggish. Currently, only eleven $(11)^{1}$ out of fiftyfive (55) countries, representing only 20 percent of the Africa continent are Contracting States to the UN Convention on Contract for the International Sales of Goods (CISG).

Commercial parties engage in the acquisition of goods for resale or business use. Traders have hoped that goods acquired will meet the details in the contract terms and accompany an elevated level of quality affirmation at a reasonable cost to give a beneficial return when put to use or resale. Generally, we expect that national laws would vary from one legal system to another and from one nation to another. For instance, in the civil law legal system, an offer is principle irrevocable while an offer is generally revocable under the common law legal system $^{2}$. Based on the difference of the revocability provisions prevailing in the different legal systems globally, the CISG drafters adopted the option of the revocability of an offer. This is contained in article 16(1) of the CISG. However, Article 16(2) rules out revocability "if it indicates, whether by stating a fixed time for acceptance or otherwise, that it is irrevocable, or if it was reasonable for the offeree to rely on the offer as being irrevocable and the offeree has acted in reliance of the offer". Furthermore, the sales contract of every country is governed by a particular legal system. Africa currently applies three (3) different legal systems. For instance, Ghana, Nigeria, and Zambia have adopted the Common law system while the civil law system governs the likes of Algeria and Gabon. The 'Mixed' system, which constitutes a combination of both common law and civil law, is adopted by countries such as South Africa and Somalia. The legal system of predominantly Islamic nations in Africa which are mostly based on French law is also gradually influenced by Islamic law. ${ }^{3}$

When parties to a contract are located in two or more separate countries, based on the Africa Continental Free Trade Area (AfCFTA), most parties to the contract are likely to come from a different jurisdiction, and there is always going to be doubt concerning the law which will apply to the transaction contract concerning the sale of goods. Although businesses often disregard the formal governing law in favor of prevailing commercial standards, the governing standards in the related nations differ. The standards of international trade also differ from those that govern trade within an individual nation. This difference justifies the need to establish uniform laws for commercial contracts.

The uniformity of laws concerning the international sale of goods has become crucial for the smooth

\footnotetext{
${ }^{1}$ The eleven African countries are Benin, Burundi, Cameroon, Egypt, Gabon, Guinea, Lesotho, Liberia, Mauritania, Uganda and Zambia.

${ }^{2}$ Huber/Mulis CISG81; Akseli in Felemegas Interpretation301; Zimmerman Obligations 560.

${ }^{3}$ Sandra Fullerton Joireman (2001), Inherited legal system and Effective Rule of Law: Africa and the colonial legacy. The Journal of Modern African Studies Vol. 39,404 pp. 571- 596.
} 
operations of African Trade. The CISG is a breakthrough effort by the UNCITRAL to unify the laws pertaining to Contracts for the International Sale of Goods. The purpose of the CISG was to offer harmonized, unbiased and uniform sales law all over the world to lessen the doubt and expenditure for transacting crossways multiple jurisdictions. ${ }^{1}$ The aim was to substitute "the multitude of anachronistic, idiosyncratic localized sales laws around the world with one, relatively simple, pragmatic set of uniform laws designed specifically for international transactions." 2

Currently, CISG has attracted attention throughout the world for its achievement in harmonizing trade law at both regional and global levels. CISG has served as a standard for the amendment of the state's sales laws. A typical example is Article 2 of the American Uniform Commercial Code, the German Law of Obligation and the Chinese Contract Law. Most influential nations such as the United States, China, Germany, Russia, and Japan are all member states to the Vienna Convention. Interestingly all members of the G12 Group ${ }^{3}$ except the United Kingdom are members of the CISG.

However, many countries still doubt how CISG would be in practice in their domestic laws. The ratification of the Convention is just not perceived as a matter of relevance in some African nations. Most countries also assume there are more important economic issues than the adaptation of the Convention. ${ }^{4}$ The adaptation of the Convention will in one way or the other require some resources like funds and time which some countries are not eager to use.

As of 2020, 94 countries have ratified CISG and are known as member states to the Vienna Convention. ${ }^{5}$ In this context, ratification means 94 nations have assented to, approved, accepted or succeeded to the Convention. ${ }^{6}$ However, only eleven $(11)^{7}$ out of fifty-five (55) countries in Africa are contracting states to CISG, approximately $20 \%$ of the continent.

\section{CISG in a Nutshell}

\subsection{Background History of the CISG}

Over the past forty (40) years, the CISG has played a significant role in the removal of legal barriers among nations, leading to the facilitation of international trade by aiding its sustainable growth. According to numerous researchers, the result of the CISG is barely efforts that existed for about 50 years to be drafted and brought into force. ${ }^{8}$ Nevertheless, it is also "a product of more than two generations of international negotiations." 9 According to history, its legality is prejudiced by a double international organization, the International Institute for the Unification of Private Law (UNIDROIT) and the UNCITRAL. The UNIDROIT led to the adoption of two uniform laws, which were the Uniform Law on the Formation of Contracts for the International Sales of Goods (ULFIS) and the Uniform Law on the International Sales of Goods (ULIS) which are predecessors of the CISG. With regards to UNCITRAL, it attained the growth of the CISG. The development of the CISG started in the $1920 \mathrm{~s} .{ }^{10}$ It was led by the International Institute for the Unification of Private Law (UNIDROIT) which was founded on 3rd September 1926, in Rome and was inaugurated on 30th May 1928. ${ }^{11}$ The Hague Conference for Private International Law and finally the UNCITRAL. ${ }^{12}$ At the same time (1928) where the International Institute for the Unification of Private Law (UNIDROIT) was founded, Ernst Rebel proposed to work towards the unification of international sales law. ${ }^{13}$ In 1929, the general principles of the vision were outlined by Ernst

\footnotetext{
${ }^{1}$ Lisa Spagnolo, "The Last Outpost: Automatic CISG Opt Outs, Misapplications and the Costs of Ignoring the Vienna Sales Convention for Australian Lawyers" (2009) 10 Melbourne Journal of International Law 141, 145-146 (hereafter, Spagnolo, “The Last Outpost”).

${ }^{2}$ Ibid.

${ }^{3}$ The Group of G12 is a group of thirteen industrially advanced countries whose central banks co-operate to regulate international finance. They are Australia, Belgium, Canada, France, Germany, Italy, Japan, Netherlands, Spain Sweden, Switzerland, UK and USA

${ }^{4}$ Sons “Japan's Accession to the CISG: The Asian Factor" (2018) Pace International Law Review, 105.

${ }^{5}$ As of 2020, the following nations were recognized as members of the CISG: Albania, Argentina, Armenia, Australia, Austria, Azerbaijan, Bahrain, Belarus, Belgium, Benin, Bosnia and Herzegovina, Brazil, Bulgaria, Burundi, Cameroon, Canada, Chile, China, Colombia, Congo, Costa Rica, Croatia, Cuba, Cyprus, Czech Republic, Democratic People's Republic of Korea, Denmark, Dominican Republic, Ecuador, Egypt, El Salvador, Estonia, Fiji, Finland, France, Gabon, Georgia, Germany, Greece, Guatemala, Guinea, Guyana, Honduras, Hungary, Iceland, Iraq, Israel, Italy, Japan, Kyrgyzstan, Latvia, Laos, Lebanon, Lesotho, Liberia, Liechtenstein, Lithuania, Luxembourg, Madagascar, Mauritania, Mexico, Moldova, Mongolia, Montenegro, Netherlands, New Zealand, North Macedonia, Norway, State Palestine, Paraguay, Peru, Poland, Republic of Korea, Republic of Moldova, Romania, Russian Federation, Saint Vincent and the Grenadines, San Marino, Serbia, Singapore, Slovakia, Slovenia, Spain, Sweden, Switzerland, Syrian Arab Republic, The former Yugoslav Republic of Macedonia, Turkey, Uganda, Ukraine, United States of America, Uruguay, Uzbekistan, Vietnam and Zambia

${ }^{6} \mathrm{https}$ //treaties.un.org/Pages/ViewDetails.aspx?src=TREATY\&mtdsg_no=X-10\&chapter=10\&clang=_en.

${ }^{7}$ The eleven African countries are Benin, Burundi, Cameroon, Egypt, Gabon, Guinea, Lesotho, Liberia, Mauritania, Uganda and Zambia.

${ }^{8}$ Schwenzer/Hachem http://ius.unibas.ch/uploads/publics/6248/201109131645024e6f6c6e5b746.pdf McNamara 2003 (32) Colorado Lawyer11.

${ }^{9}$ Krieger 1989 (106).

${ }^{10}$ Ibid

${ }^{11}$ Ibid

${ }^{12}$ Peter Huber, Alastair Mullis, The CISG: A new Textbook for Students and Practioners (1st edn, sellier. European law publishers 2007) 2.

13 Ingeborg Schwenzer, Pascal Hachem, 'The CISG - A Story of Worldwide Success' 
and his co-workers. A year later, in 1930, a committee comprised of a renowned group of European scholars and representatives from diverse legal systems was created. The maiden draft of a uniform law was issued in 1935 after five years of the formation of the committee. Due to World War II, the development went to a halt. In January 1951, the government of Dutch held a diplomatic conference with a recognized special commission to make advance development in the unification of sales progress. In the end, 28 countries met in April 1964 at the Diplomatic Conference at The Hague. ${ }^{1}$ Two conventions, specifically the ULFIS and the ULIS, were finalized. ${ }^{2}$ Nonetheless, both maiden uniform sales laws achieved minimal expectation and only nine states ${ }^{3}$ ratified and became members. That notwithstanding, their practical significance should not be underrated.

The initial participant of the UNCITRAL was arithmetically allocated in favor of Africa with seven seats alongside five from Asian countries, Eastern European countries had four, Latin American Countries had five and Western European and other countries had eight seats. ${ }^{4}$ The General Assembly of the United Nations provided a resolution for the formation of a world representative group in 1966 to encourage the progressive harmonization and unification of the law of international trade. ${ }^{5}$ A working group was set up by the UNCITRAL during its first meeting from 29th January to 26th February which was held at United Nations Headquarters. Its role was to modify the ULFIS and the ULIS or to propose a well-structured convention with a greater chance of high acceptance in the world. ${ }^{6}$ Just after the formation of the UNCITRAL, the commission held its initial and subsequent meetings on $29^{\text {th }}$ and $30^{\text {th }}$ January 1968 respectively. Right then, Africa played a substantial role as the commission elected its first Chairperson in the person of Ambassador Emmanuel Kodjoe Dadzie the Ghanaian representative. ${ }^{7}$ During this session, work on harmonization of international sales law was prioritized. ${ }^{8}$ Three Africa nations, namely Ghana, Kenya and Tunisia were members of the first working Group on the Uniform Rules Governing the International Sales of Goods and Law Applicable. ${ }^{9}$ Furthermore, when the final draft of the CISG was finalized in the year 1978, the UNCITRAL Chairperson was the former Justice Date-Bah of the Supreme Court of Ghana. ${ }^{10}$ Considering the above, it is an indisputable fact that Africa nations were participating right from the period of the UNCITRAL formation and the works of the UNCITRAL.

From March 10th to 5th April 1980, at the renowned Vienna session, representatives from sixty-two countries deliberated the Vienna Convention where forty-two out of sixty-two nations voted in favor of the Contract for International Sales of Goods. The number required for ratification was reached on 11th December 1986, and the Vienna convention was entered into force on 1st January 1988. The official languages are Arabic, Chinese, English, French, Russian and Spanish. ${ }^{11}$ The Vienna Convention is currently the modernization of some state laws across the world. Such as Chinese law, German, Russian, Dutch, Estonian and Scandinavian.

\subsection{Applicability of the CISG}

Transcontinental trade is rapidly becoming a commercial norm. Africa as a continent has been trading mainly with other continents across the world. ${ }^{12}$ The AfCFTA established in March 2018 has recently commenced trading under the free trade area on the 1 st January $2021^{13}$. One of the objectives of the AfCFTA is to boost intra Africa trade. To attain such an objective, there is a need for regulations that guide international business in Africa. The CISG in this regard adds meaningfully and increases the level of certainty in commercial transactions and reduces the contract costs of international trade. Most traders in Africa may have their place of business in a noncontracting nation but, the rule of private international law in most cases will bring about the applicability of the Convention (Art.1 (1) (b) CISG). Subject to the reservations provided for Art.92 et seq. CISG, virtually all contacts on sales of goods fall within the influence of the Convention. The Convention will fail to

\footnotetext{
<http://ius.unibas.ch/uploads/publics/9587/20110913164502 4e6f6c6e5b746.pdf> accessed 12 May 2019.

${ }^{1}$ Lookovsky (n 8) 4; Huber, Mullis (n 14) 3.

${ }^{2}$ Ibid

${ }^{3}$ Namely Belgium, Gambia, Germany, Italy, Luxembourg, the Netherlands, San Marino, the United Kingdom and Israel.

${ }^{4}$ The United Nations General Assembly Resolution 2205 (XXI) of 17 December 1966 section II para (1) in UNCITRAL United Nations Commission on International Trade Law Yearbook Volume I: 1968-70 (1971) 66. Members from African states were Nigeria, Tunisia, Democratic Republic of Congo, Kenya, Tanzania, Ghana and the United Arab Republic (now Egypt). See Annual Report of the Commission (1968) in UNCITRAL United Nations Commission on International Trade Law Yearbook Volume I: 1968-70 (1971) 72

${ }^{5}$ UNCITRAL, A Guide to UNCITRAL: Basic facts about the United Nations Commission on International

Trade Law (UNITED NATIONS Vienna 2013) 1.

${ }^{6}$ UNGA 'Report of the UN Commission on International Trade Law on the work of its first session` UN GAOR 23rd Session Sup No 16 UN Doc A/7216 (1970) 72, online at

http://www.uncitral.org/pdf/english/travaux/sales/limit/a7216-e.pdf

${ }^{7}$ Report of the Commission: I. the Frist Section (1968) n UNCITRAL United Nation Commission on International Trade Law Yearbook Volume I: 1968-70(1971) 73

${ }^{8}$ Ibid.

${ }^{9}$ Date-Bah 2011 European Journal of Law Reform 362

${ }^{10} \mathrm{Ibid}$

${ }^{11}$ Honnold (n 7) 12.

${ }^{12}$ African Union, 'Flagship Projects of Agenda 2063' (The African Union) <https://au.int/agenda2063/flagship-projects>.

13 'Status of AfCFTA Ratification' [2019] Tralac <https://www.tralac.org/resources/infographic/13795-status-of-afcfta-ratification.html $>$.
} 
apply if the vendor transacts from a place that is a non-contracting state and the absence of an expressed and an implicit choice of the law of a contracting state.

2.2.1 The applicability of CISG based on the condition of "internationality"

The CISG only applies to contracts of sales of goods between parties whose "place of business" is not in the same country. Different nations mean the two parties to a contract of sales of goods are from two separate nations. For instance, $\mathrm{X}$ and $\mathrm{Y}$ are parties to a contract. X's place of business is in Zambia and Y's place of business is in Egypt. CIGS is applicable here. Goods need to be transferred from Lusaka (Capital of Zambia) to Cairo (Egypt Capital city).

Place of business is considered as where a business is registered. If a party to the contract has more than one business place, Subject to article 10(a) of the Convention, the place of business is considered to be the one that has the closest relationship to the contract and its performance. For instance, if a seller has a place of business in two countries say, Nigeria and Ghana, and the purchaser has a place of business in Nigeria. Assuming that in making the contract, its performance is close to Nigeria than to Ghana, it will be considered that the seller's place of business is in Nigeria and on this note, CISG is not applicable since Nigeria is not a foreign country in this instance.

2.2.2 The applicability of the CISG based on "The Relationship with the Contracting State"

The application conditions are either direct application or indirect application: The CISG is directly ${ }^{1}$ applicable when parties to a contract have a business place in the different contracting states, based on the principle outlined in Article I (I) (a) ${ }^{2}$. It does not matter even where the parties are oblivious about the fact that the place of business of the states is the contracting states. However, the applicability of the CISG is not exempted where the parties do not have their business places in the different contracting states. CISG can equally be applicable although one or both parties do not have their place of business in the contracting states, provided that the rules of private international law lead to the application of the law of a contracting state, according to Article I (I) (b). For CISG to be directly applicable, Art.1 (1) (a) CISG offers two options that have to do with the place of business in different states and these states are the Contracting States. For the CISG to be indirectly applicable, parties should have places of business in different states that need not be the Contracting States. According to Art. 1(1) (b), there should be the rules of private international law to the application of the law of the contracting state. Article 1(1) (b) simply means that parties in non-contracting states might be subject to laws that their country has not ratified with regards to the applicability of the CISG. This challenge had received several protestations that were finally recognized merely based on the justification for conciliation permitting a reservation $^{3}$, and allowing the ratifying state to affirm that it would not be bound by article 1(1) (b). This means that the CISG will only be applicable if both parties had their places of business in different contracting states. Conventionally, Article 95 states that any nation may declare that it will not be bound by Article 1(1) (b) at the time of submitting its instruments of ratification. ${ }^{4}$ The original CISG Draft did not comprise Article 95 reservation. It was formally introduced by the Czechoslovakian delegation in the 1980 Vienna Diplomatic Conference to enable ratification by Communist nations. ${ }^{5}$

Unfortunately, the likes of China and the United States, which are significant countries regarding trade have made such reservations. ${ }^{6}$ This has concerned many scholars' consideration and, thus, some misunderstanding. ${ }^{7}$ Nonetheless, the CISG offer freedom to a contract, for instance, Art.6 of the CISG permits parties the right to determine provisions of the Contract, it also establishes the primacy of part autonomy over the CISG. Hence the parties are free to alter the effect of the CISG or to disregard it entirely or partly.

2.2.3 The Applicability of CISG based on sales of Goods.

Mainly, goods are tangible substances. According to the Convention, specific industrial rights and intellectual property rights are not considered goods. Goods such as stocks, bonds, negotiable instruments, crafts and electrical energy which are regarded as goods in certain jurisdictions are also not considered as goods under CISG. ${ }^{8}$ Furthermore, consumable goods that are purchased for personal and household use are usually left out.

Sales are regarded as an exchange of goods for money. Barter contracts (Exchange of good for good) are not sales. Auctions sales are exempted since auctions are held usually locally and seldom internationally as at the period of the drafting of CISG. Nevertheless, there have been changes and it has been debated by many scholars as to whether consenting electronic cross-border auctions should be ruled by the CISG or should be narrowed to

\footnotetext{
${ }^{1}$ Ferrari, supra note 100 , at 13 .

${ }^{2}$ Article 1(1) of the CISG states that: "This Convention applies to contract of sale of goods between parties whose places of business are in different States:(a) when the State are Contracting States; or (b) when the rule of private international law led to the application of the law of the Contracting State."

${ }^{3}$ CISG, above $\mathrm{n} 3$, art 95

${ }^{4}$ http://cisgw3.law.pace.edu/cisg/biblio/yang2.html; Wethmar-Lemmer PIL 124-145.

${ }^{5}$ Bell 2005 (9) Singapore YB of International Law 55; Schlechtriem/Schwenzer/ Hachem in Schlechtriem/Schwenzer Commentary 1190.

${ }^{6}$ Peter Schlechtriem in Schlechtriem and Schwenzer, above n 2, art 1, paras 42 and 43, art 95, para 4.

Ibid.

${ }^{8}$ CISG, above note 3 , art $2(\mathrm{e})$
} 
domestic auctions according to Article 2(b). Nonetheless, the Vienna Convention goes far beyond only sales of goods. It commands its application to mixed contracts based on Article 3(2). A mixed contract is where a party to the contract being the buyer or seller is not obliged to merely deliver or supply goods but also to provide certain additional services. ${ }^{1}$ For instance, the seller of a particular plant and machinery has been contracted to erect the plant in the factory of the buyer in addition to the delivery of the plant. A mixed contract has to be termed completely as a sale or it has to be split into a service contract or sale contract. The CISG decided on treating the mixed contract as a unitary contract provided the larger part of the contract is the delivery of goods. ${ }^{2}$

\subsection{The key Provision of the CISG}

The CISG like many multilateral treaties has well thought out provisions that guide its usage or application. These provisions spell out the rules of engagement and avoid ambiguity in international trade. Contractual transactions relating to the international sale of goods between private businesses are governed by CISG. This, however, excludes sales of service and sales of some specified types of goods. The effect and validity of the contract on goods sold fall outside the scope of the Convention. Also, the CISG captures how contracts are formed, which is summarized by the exchange of offer and acceptance.

Another aspect worth considering is that CISG captures the obligation of the contracting parties. The seller's obligations as captured by CISG include the delivery of goods in conformity with the specifications under the contractual agreement as well as related documents and transferring the property in the goods. The purchaser's obligation under CISG includes payment of the price and taking the title of the goods. The CISG captures the remedies available to parties on a breach of contract. The party at a disadvantage may require the execution of specific performance, claim for damages or terminate the contract in the situation of a breach of the fundamental agreement. Another provision of the CISG regulates the passage of risk, anticipatory breach of contract, damages and exception to the performance of the contract. Lastly, CISG permits the freedom of the form of the contract. However, the States may lodge a declaration requiring the written form.

\subsection{The significance of the CISG in Harmonization of International Sales Laws.}

The uniformity of law concerning the international sale of goods has become crucial for the smooth operations of African Trade. The CISG is a breakthrough effort by the UNCITRAL to unify the laws pertaining to the international sale of goods. Clearly, creating consistency and predictability is the guarantee of legitimate harmonization. Harmonization of laws such as the Principles of European Contract Law (PECL), the Africa OHADA uniform Act of General Commercial Law, the UNIDROIT Principle of International Commercial Contract (PICC) and the Common European Sales Law have all been influenced by the CISG. Most harmonized laws were primarily based on the CISG. The CISG has had a huge impact at the universal level just as at the local level. Its impact is considerable and pervasive. ${ }^{3}$ The huge volumes of exchange of goods across the world conducted under the Convention indicate that legal professionals have picked up assurance in the CISG. There's a need to instruct upcoming Africa legal experts about the significance of the CISG to contribute to an expansion in the adoption of the Convention.

Article 7(1) of the CISG requires that there should be uniformity in the interpretation of the Convention. The Convention states that in its interpretation, "regard is to be had to its international character and the need to promote uniformity in its application and the observance of good faith in international trade". Therefore, the courts and tribunals are authorized to interpret and apply the Convention in a manner consistent to build a uniform sales law. ${ }^{4}$ Accepted, there have been problems concerning the interpretation of the CISG. Many scholars and legal practitioners have criticized the Convention's ambiguous and imprecision terms. The criticism centered on a lack of uniformity is largely established on erroneous evidence. ${ }^{5}$ Never can the CISG achieve a strict uniform application. As stated by Honnold: "Throughout the work on a uniform, realists have told us, even if you get uniform laws, you won't get a uniform result. Those sad-faced realists were dead right as confirmed bachelors and spinsters who build their lives on the realistic view that there is no perfect spouse." 6

\footnotetext{
${ }^{1}$ Ulrich Schroeter "Vienna Sales Convention: Applicability to 'Mixed Contracts' and Interaction with the 1968 Brussels Convention" (2001) 5 Vindobona Journal of International Commercial Law and Arbitration 74.

${ }^{2}$ Paragraph 2 of Article 3 of the CISG governs the applicability of the Convention to mixed contracts. According the said paragraph, the CISG does not apply to the contract where the preponderant part of the obligations of the party who provides the goods is to supply labour or other service.

${ }^{3}$ Bonell An International Restatement of Contract Law: The UNIDROIT Principles of International Commercial Contract 3 edition (205) 305-306.

${ }^{4}$ Torsello Common Features of Uniform Commercial Law Conventions: A Comparative Study Beyond the 1980 Uniform Sales Law (2004) 18 .

Ibid.

${ }^{6}$ Honnold “The Sales Convention in Action - Uniform International Words: Uniform Application?” 1988 Journal of Law and Commerce 207.
} 


\section{The Benefit of the Ratification of the CISG on the AfCFTA}

There are serval benefits the ratification of the CISG will bring to the AfCFTA. The first of it is the elimination of cost relating to the negotiation of governing law of the contract of sales whenever parties to a contract are located in a different contracting state. The sales contract of every country is governed by a particular legal system. Africa currently applies three (3) different legal systems. Such negotiation is costly and takes a long duration, especially in situations where there is a perceived difference in the laws of the parties involved or when it gives a preferential advantage to one party. In the case where there is independence and an equal footing in the negotiation, the issues could be overlong. Where there is unequal footing relating to bargaining power or negotiation ability, the preference of one party is likely to prevail at the expense of the party at the weaker side of the negotiation. In the case of International trading between one party from an underdeveloped nation in Africa and another in a developed country, there is a high possibility that the party from an underdeveloped nation in Africa would be the less advantageous party on the grounds of limited negotiation skills. However, the implementation of CISG by all African countries may eliminate such demerits to the African party in the contract.

Furthermore, if there is an international contractual dispute among African countries and one party is not a contracting state of CISG and its foreign counterpart is governed by the CISG, Article 1(1) (b) of the CISG is applicable and the rules of a dispute of law may by chance lead to the laws of that jurisdiction. This is because Article 1(1) (b) of the CISG is applicable "when the rules of private international law result in the application of the law of the contracting State". This mode of application is usually described as indirect ${ }^{1}$. Article 95 indicates that contracting states are not tied to this indirect means of application and therefore contracting states can make such declaration. However, most contracting States fail to make such a declaration ${ }^{2}$. None of the eleven (11) African countries contracting states of the CISG has made such declaration. There is, therefore, the possibility that African countries that are not contracting states or located parties together with their lawyer may indirectly apply the CISG. In a situation like that, the parties and their lawyers may find themselves wanting in terms of necessary understanding and application of CISG, which could have implications for the administration of Justice.

Also, gaining access to CISG by African businesses may help minimize transaction costs and increase efficiency between parties to a contract among African countries and other continents. There is no doubt that foreigners seeking to do business in some parts of Africa find it very difficult or challenging to gain access to domestic Laws. Foreigners who want to get acquainted with African Laws relating to the international contract of sales of goods will have to resort to the services of African Lawyers which is very costly and time consuming. Such cost may serve as a hindrance to the transaction or if the transaction is ongoing, there is a likelihood of it manifesting through an increase in the domestic price of goods. In this global world of intensified competition, a rise in transactional cost will reduce one's competitive edge of doing business with African located parties. All other things being equal, a rational foreign purchaser who has access to different sources of supply may eventually choose the country with far fewer costs. The cost of such a nature may be avoided if all African countries adopted the CISG, as the implementation would be made publicly available, making Africa's stands readily available to potential traders with African counterparts.

Lastly, the perceived image of Africa will be enhanced within the international business community upon choosing to implement CISG, as the entire African countries go public about their intention to adopt the internationally accepted laws and conventions. This may help mitigate the perception being it right or wrong that transaction with African countries is risky on account of but not limited to unpredictable laws and unreliable standards.

The benefits that potentially come with the CISG in AfCFTA are of much significance. Wider unified markets may potentially attract more investors from other regions and along with new venture opportunities which could bring new technologies and innovative ideas that will positively impact the production capacity. As AfCFTA strives to become more united, efforts should be made to ensure enough policy convergence and flexibility in rules throughout the various trading regimes.

\section{Conclusion}

The fundamental strategies and plans of the CISG are to advance uniform laws on the global sales of goods to achieve broader approval to international trade law. In actuality, while setting up the UNCITRAL in 1966, it was

\footnotetext{
${ }^{1}$ See, for example, Spagnolo, "The Last Outpost", above note 21, 143. The direct application provision is found in Article 1(1) (a), which provides that the Convention applies to contracts of sale of goods between parties whose places of business are in different States "when the States are Contracting States".

${ }^{2}$ Only seven (namely, China, Czech Republic, Germany, Singapore, Saint Vincent and the Grenadines, Slovakia, USA) out of the 94 Contracting States have made reservation under Article 95 to exclude or limit the application of Article 1(1)(b), See the list of Contracting States and details of their implementation at Status: UN Convention on International Sale of Goods 1980 (CISG) available at http://www.uncitral.org/uncitral/en/uncitral texts/sale goods/1980CISG status.html (last accessed 23rd March 2020).
} 
perceived that discrepancies in domestic laws created obstructions in international trade. The Vienna Sales Convention was then viewed as suitable to reduce or eliminate those hindrances. Concerning the number of contracting states and the number of accessible judicial choices based on the CISG, the Convention seems to have accomplished that aim. This declaration is upheld by the view of certain experts for whom, the CISG is "arguably the greatest legislative achievement aimed at harmonizing private commercial law." 1 The CISG, when adopted subsequently, becomes part of the domestic law of the contracting state. ${ }^{2}$ The CISG supplies all business operators globally with a similar substantive regime to be applied to the contract of sale, a similar uniform linguistic, procedure and common knowledge of fundamental issues relating to the international sale of goods contract. ${ }^{3}$ Looking at these relevancies, one might think that every nation would typically have adopted the UN Sales Convention. Nevertheless, the case is different from most African countries.

The essence for all African countries to ratify CISG is not farfetched. Considering the agenda of the AfCFTA, it is undebatable that such an agenda will not be achieved without the harmonization of its commercial laws. Besides, AfCFTA aims to increase trade in Africa. It is of much significance to acknowledge the fact that the adoption and ratification of the Instrument will progressively draw adequate foreign investors which will boost competition within other regional blocs such as the EU, ASEAN and NAFTA. ${ }^{4}$ Among the 11 Africa nations which are contracting countries to the CISG, Egypt is considered as the economic giant and the most protuberant. Awkwardly the likes of South Africa and Nigeria, the first and second economic giants are not contracting countries to the CISG. Although both countries have received calls from many scholars to approve and endorse the Convention, they are yet to comply. ${ }^{5}$

However, the CISG must not be perceived as an increasing trade instrument but rather must be perceived as a convention that will aid traders in understanding their contractual right and obligation to evade disputes.

References

'African Continental Free Trade Area: $<$ https://au.int/sites/default/files/documents/36085- doc- qa_cfta_en_rev15march.pdf $>$.

Bell, Gary F. Harmonization of Contract Law in Asia-Harmonizing Regionally or Adopting Harmonisations - The Example of the CISG. Singapore Journal of Legal Studies, 2005: 362-372.

Bonell, Michael Joachim. An International Restatement of Contract Law: The UNIDROIT Principles of International Commercial Contracts. Brill Nijhoff, 2009. 305-306.

CISG- Advisory Council Opinion No.4, Contracts for the Sales of Goods to be Manufactured or Produced and Mixed Contract (Article 3 CISG), 24th October 2004.

Ferrari, Franco. The CISG and its Impact on National Contract Law-General Report. The CISG and its Impact on National Legal Systems, 2008: 413-480.

Ferrari, Franco. What Sources of Law for Contracts for the International Sale of Goods? Why one has to look beyond the CISG. International Review of Law and Economics, 2005, 25(3): 314-341.

Honnold, John. The Sales Convention in Action-Uniform International Words: Uniform Application. Journal of Law and Commerce, 1988, 8: 207.

Huber, Peter, and Alastair Mullis. The CISG: A New Textbook for Students and Practitioners. 2007.

Institute of International Commercial Law CISG: Table of Contracting States. https://iicl.law.pace.edu/cisg/page/cisg-table-contracting-states, 2019-11-12.

Schlechtriem, Peter \& and Schwenzer, Ingeborg. Commentary on the UN Convention of the International Sale of Goods (CISG). New York: 2nd (English) edition.

Spagnolo, Lisa. The Last Outpost: Automatic CISG Outs, Misapplications and the Costs of Ignoring the Vienna Sales Convention for Australian Lawyers. Melbourne Journal of International Law, 2009, 141.

'Status of AfCFTA Ratification' [2019] Tralac <https: //www.tralac. org/resources/infographic/13795-status-ofafcfta ratification.html>.

Torsello, Marco. Common Features of Uniform Commercial Law Conventions: A Comparative Study beyond the 1980 Uniform Sales Law. Sellier European Law Publication, 2004: 18.

UN Secretary-General "LEGISLATIVE HISTORY: 1980 Vienna Diplomatic Conference. Analysis of Comments and Proposals by Governments and International Organizations on the Draft Convention on Contracts for the International Sale of Goods, and on Draft Provisions Concerning Implementation, Reservations and Other Final Clauses Document A/CONF.97/9. http://www.cisg.law.pace.edu/cisg/confere

\footnotetext{
${ }^{1}$ Ferrari 2005 (25) International Review of Law and Economics 314.

${ }^{2}$ Zeller 2002 (14) Pace Int'l LR163.

${ }^{3}$ Kröll/Mistelis/Viscasillas UN Convention5-6 §10.

${ }^{4}$ Bell, G. F. (2005). Harmonization of Contract Law in Asia-Harmonizing Regionally or Adopting Global Harmonizations-The Example of the CISG. Sing J. Legal Stud., 362.

${ }^{5}$ Castellani, L. (2010). Promoting the Adoption of the United Nations Convention on Contracts for the International Sale of Goods (CISG). p.4.
} 
nce.html, 2020-03-15.

UNCITRAL Secretariat Explanatory Note by the UNCITRAL Secretariat on the United Nations Convention on Contracts for the International Sale of Goods (United Nations document V.89-53886 June 1989).

UNCITRAL. Report of the Working Group on International Sale of Goods, First Session, 5-10 January 1970. Yearbook of the United Nations Commission on International Trade Law, 1970, 1:177.

UNCITRAL. UN Convention on International Sale of Goods 1980 (CISG). http://www.uncitral.org/uncitral/en/uncitral_texts/sale_goods/1980CISG_status.html, 2020-03-20.

Zeller, Bruno. The Development of Uniform Laws-A Historical Perspective. Pace International Law Review, 2002, 14: 163. 